\title{
In vitro potential activity of some seaweeds as antioxidants and inhibitors of diabetic enzymes
}

\author{
Gehan Ahmed ISMAIL ${ }^{1}\left(\mathbb{D}\right.$, Saly Farouk GHEDA $^{1}\left(\mathbb{D}\right.$, Atef Mohamed ABO-SHADY ${ }^{1}$, Omnia Hamdy ABDEL-KARIM ${ }^{1 *}$
}

\begin{abstract}
In this study crude extracts of Turbinaria decurrens, Padina pavonica, Sargassum muticum and Sargassum acinarium (Phaeophyta); Ulva lactuca (Chlorophyta) and Pterocladia capillacea (Rhodophyta) seaweeds were tested to evaluate their antioxidant properties and antidiabetic potential on $\alpha$-amylase and $\alpha$-glucosidase starch hydrolyzing enzymes. The results showed that all analyzed seaweeds exhibited antioxidant effects using DPPH (2,2-Diphenyl-1-picrylhydrazyl), reducing power and total antioxidant capacity assays in addition to antidiabetic activity that all depended on the species and the extract solvent. Among the tested extracts, acetone extract of Turbinaria decurrens showed the highest antioxidant activity and inhibitory effects for $\alpha$-amylase (96.1\%) and $\alpha$-glucosidase (97.4\%), respectively which was related with its total phenolic content and antioxidant activity. In vitro, the extract showed no toxicity against fibroblast normal cell lines at lower concentration of $250 \mu \mathrm{g} / \mathrm{ml}$. Gas Chromatography-Mass Spectrum analysis (GC-MS) of this acetone extract showed the presence of different bioactive compounds mainly cyclotrisiloxane, hexamethyl which could be responsible for its antioxidant and antidiabetic activities. The study results suggest that brown seaweeds especially $T$. decurrens can be used as antioxidant ingredients and as potent reducing drug for postprandial hyperglycemia.
\end{abstract}

Keywords: seaweeds; antioxidant; antidiabetic; cytotoxicity; GC-MS analysis.

Practical Application: Looking for new natural supplies proved to be safe, economic and eco-friendly such as seaweeds used as food, antioxidant and as a potent drug for diabetes.

\section{Introduction}

The term of seaweeds refers to the large visible macro-algae growing attaching to rocks and along the sea shore and they are found in a range of aquatic habitats (Raven \& Giordano, 2014). They are categorized based on their pigments content, morphological and anatomical attributes into three divisions which are red algae (Rhodophyceae), brown algae (Phaeophyceae) and green algae (Chlorophyceae) (Manivannan et al., 2009). There is an excessive interest for screening helpful medications from marine algae as they contain bioactive compounds, e.g., polysaccharides, pigments, proteins, lipids, peptides, minerals and vitamins (Husni et al., 2016). They have diversified biological activities, such as anti-hypertensive, anti-hyperlipidemic, anti-coagulant, apoptotic activities (Lee \& Han, 2012), antioxidant, anti-inflammatory and anticancer (Khalid et al., 2018). They also could play an important role in the control of diabetes (Unnikrishnan et al., 2015) by regulation of glucose-instigated oxidative stress and suppression of starch hydrolyzing enzymes (Husni et al., 2016).

In the body, biochemical pathways of metabolism may produce reactive oxygen species (ROS), as intermediate hazardous products which, upon excess- abundance creation, the body will not be able to neutralize or detoxify these free radicals thus causing oxidative stress impact (Santos-Sánchez et al., 2019). This resulted in oxidative impairment of cell components such as protein denaturation, lipid peroxidation and/or DNA conjugation. Recently, oxidative stress has been related with many diseases like cancer, diabetic, cardiovascular diseases, Parkinson's and Alzheimer disease, post-ischemic and neural degradation disease (Pirian et al., 2017). Antioxidants are compounds that stop or interrupt the oxidation process in cells by scavenging free radicals and hence prevent or mitigate diseases (Kokabi et al., 2013). There are many artificial antioxidant substances, yet with unsafe effects. Thus, exploring new natural antioxidants have been a challenge target. In this concern, marine seaweeds have been known as traditional sources of natural antioxidants (Samaraweera et al., 2012).

Diabetes mellitus is a metabolic disturbance having the feature of hyperglycemia requiring continuous medical care, which occurs primarily because of a relative or absolute absence of insulin, weakened viability of insulin activity or tissue impedance to insulin (American Diabetes Association, 2014). Insulin, a hormone created by the $\beta$-cells of pancreas, functions to keep up a strict control of the blood glucose. This hormone enables the tissues and the body cells to consume glucose for energy. Insulin absence or disabling of its activity causes tissues and cells insensitivity, thus can't utilize glucose causing an increased level of glucose in the blood, which leads to diabetes (Akpaso et al., 2017).

Diabetes is basically related with hazardous difficulties including hypertension, nephropathy retinopathy, and other 
cardiac diseases (Pamungkas \& Chamroonsawasdi, 2019). Two principle types of diabetes mellitus were known: type 1 and type 2. Type 1 diabetes (or Insulin Dependent Diabetes Mellitus (IDDM)) accounted for around $10 \%$ of all diabetes cases and rottenly occurs in individuals under age of 40 years. In this type a normal lack of insulin release occurs which causes damaging of the $\beta$-cells in pancreas (Vasudevan \& Sreekumari, 2011). Alternatively, type 2 diabetes effects about $90 \%$ of persons that are at or more 40 years old. In this type, insensitivity of tissues to insulin stimulating weakened insulin activity and sometimes, high levels of insulin (Vasudevan \& Sreekumari, 2011). Enzymes, such as, $\alpha$-amylase and $\alpha$-glucosidase in humans body act in harmony to hydrolyze starch by pancreatic $\alpha$-amylase and to absorb glucose by intestinal $\alpha$-glucosidase which may swift postprandial hyperglycemia (Unnikrishnan et al., 2015).

The aim of this study was to evaluate, in vitro, the antioxidant and antidiabetic activities of six different seaweeds collected from different locations in Egyptian coasts. The study was extended to test the cytotoxicity of the most promising seaweed extracts and to identify the most active compounds that responsible for the antioxidant and antidiabetic activities using GC-MS analysis.

\section{Material and methods}

\subsection{Collection of seaweed samples}

Different types of seaweeds were collected from Abou Qir Bay, Alexandria (Ulva lactuca, Padina pavonica and Pterocladia capillacea) and Hurghada beach, Egypt (Turbinaria decurrens, Sargassum muticum and Sargassum acinarium) during Summer of 2017. The gathered seaweeds were imparted to the phycology laboratory in plastic bags containing seawater to counteract vaporization. The gathered seaweeds were cleaned utilizing the tap water then with refined water for removing joined epiphytes and non-living network. A portion of the gathered samples were preserved in $0.4 \%$ formalin in seawater for taxonomical identification and the remaining portion was dried in the air on retentive papers, under shadow, at room temperature of $25-30{ }^{\circ} \mathrm{C}$. The dried examples were powdery grinded using an electrical mill, then stored until use. The seaweed samples were identified according to Aleem (1993), Jha et al. (2009) and Guiry \& Guiry (2019).

\subsection{Preparation of seaweed extracts.}

The dried seaweed samples were extracted using $80 \%$ of various organic solvents such as acetone, ethanol and methanol as well as distilled water for $72 \mathrm{~h}$ by using shaking incubators in a dark condition. After being filtered, each filtrate was concentrated to dryness under reduced pressure using a rotary evaporator. The samples were finally stocked in a refrigerator at $2-8{ }^{\circ} \mathrm{C}$ for use in the subsequent experiments.

\subsection{Preliminary phytochemical screening}

Typical procedures described by Andima et al. (2014) were used for chemical identification of the phyto-components present in the various extracts.

\subsection{Antioxidant assays}

\section{DPPH free radical scavenging assay}

DPPH free radical scavenging was determined according to the procedures described by Ul-Haq et al. (2012). In a glass tube, $2800 \mu \mathrm{L}$ of $0.1 \mathrm{mM}$ methanolic DPPH (Sigma, St. Louis, USA) solution were mixed with $200 \mu \mathrm{l}$ of the test sample. The tubes were shaken well and kept away from the light for 60 minutes at $37^{\circ} \mathrm{C}$. The tubes were then centrifuged (Fisher Scientific 225 Centrifuge) at $3000 \mathrm{rpm}$ for $5 \mathrm{~min}$. The absorbance of the reaction mixtures was measured at $517 \mathrm{~nm}$ on a spectrophotometer. Ascorbic acid was used as a positive control. The percentage of DPPH free radical scavenging for each sample was calculated by using the following formula (Ul-Haq et al., 2012):

$$
\% \text { Inhibition }=\frac{\text { Absorbance of control }- \text { Absorbance of test sample }}{\text { Absorbance of control }} \times 100
$$

The $\mathrm{IC}_{50}$ values were also calculated using GraphPad prism 6 software.

\section{Reducing power assay}

The method of Mohapatra et al. (2016) was used to assess the reducing power activity of the different seaweed extracts. $1 \mathrm{ml}$ of each extract was mixed with $2.5 \mathrm{ML}$ of $0.2 \mathrm{M}$ sodium phosphate buffer ( $\mathrm{pH} 6.6$ ) and $2.5 \mathrm{~mL}$ of $1 \%$ potassium ferricyanide then incubated in a water bath at $50{ }^{\circ} \mathrm{C}$ for $20 \mathrm{~min}$. After that, $2.5 \mathrm{ml}$ of $10 \%$ trichloroacetic acid was added and centrifuged at $3000 \mathrm{rpm}$ for $10 \mathrm{~min}$. The supernatant $(2.5 \mathrm{~mL}$ of each) was then diluted with $2.5 \mathrm{~mL}$ distilled water and then $0.5 \mathrm{ml}$ of $0.1 \%$ ferric chloride solution was added. The intensity of the blue-green color was measured at $700 \mathrm{~nm}$. The results were expressed as $\mathrm{mg}$ of ascorbic acid equivalent/g dry weight (mg AAE/g DW). Ascorbic acid was used as standard. Tests were carried out in triplicate.

\section{Total antioxidant capacity assay}

The total antioxidant capacity (TAC) was determined following Ahmed et al. (2013). Each test extract $(0.3 \mathrm{~mL})$ was mixed with $3 \mathrm{~mL}$ phosphomolybdenum reagent in a capped vial and incubated in a boiling water bath at $95^{\circ} \mathrm{C}$ for $90 \mathrm{~min}$. After that, the samples were cooled at room temperature and the absorbance was measured at $695 \mathrm{~nm}$. Ascorbic acid was used as a reference and the results were expressed as mg ascorbic acid equivalent /g dry weight of the extract.

\subsection{Total phenolic content}

The total phenolic concentration was measured using the Folin-Ciocalteau method (Cox et al., 2010). In this procedure, $100 \mu \mathrm{L}$ of each sample extract were mixed with $2.0 \mathrm{~mL}$ of $2 \%$ $\mathrm{Na}_{2} \mathrm{CO}_{3}$ and allowed to stand for $2 \mathrm{~min}$ at room temperature. Then, $100 \mu \mathrm{L}$ of $50 \%$ Folin - Ciocalteau's phenol reagent were added and incubated for $30 \mathrm{~min}$ at room temperature away from the light. The absorbance was measured at $720 \mathrm{~nm}$. Gallic acid was used as a positive control. The total phenolic contents of the samples were expressed as $\mathrm{mg}$ Gallic acid equivalent per gram extract dry weight (mg GAE/g DW). 


\subsection{Antidiabetic assay}

In vitro $\alpha$-amylase inhibition

The inhibitory activity of $\alpha$-amylase was determined according to Schomburg \& Salzmann (1991). $250 \mu \mathrm{L}$ of each extract were added to $250 \mu \mathrm{L}$ of $1 \mathrm{mM}$ phosphate buffer ( $\mathrm{pH} 7.3$ with $30 \mathrm{mM} \mathrm{CaCl}$ ) containing $0.5 \mathrm{mg} / \mathrm{mL}$ a-amylase (porcine pancreatic alpha-amylase Sigma, St. Louis, USA) then, the solution was incubated for $10 \mathrm{~min}$ at $25^{\circ} \mathrm{C}$. After incubation, $250 \mu \mathrm{L}$ of $1 \%$ soluble starch solution in $1 \mathrm{mM}$ phosphate buffer ( $\mathrm{pH} 7.3$ with $30 \mathrm{mM} \mathrm{CaCl}_{2}$ ) were added and incubated again at $25^{\circ} \mathrm{C}$ for $10 \mathrm{~min}$. The reaction was shut-off by adding $500 \mu \mathrm{L}$ of dinitrosalicylic acid color reagent (Sigma, St. Louis, USA). The tubes were then incubated in a boiling water bath for $5 \mathrm{~min}$ after that, cooled to room temperature. The mixture was then diluted by adding $5 \mathrm{~mL}$ of distilled water, and then the absorbance was measured at $540 \mathrm{~nm}$. The tests were done in triplicates, and the inhibitory activity of a -amylase was expressed as (Unnikrishnan et al., 2015):

$\%$ Inhibition $=\frac{\text { Absorbance of control }- \text { Absorbance of extract }}{\text { Absorbance of control }} \times 100$

Concentrations of the most promising extract resulting in $50 \%$ inhibition of the enzyme activity $\left(\mathrm{IC}_{50}\right)$ were determined by GraphPad prism 6 software.

\section{In vitro $\alpha$-glucosidase inhibition}

The effect of the seaweed extracts on the activity of $\alpha$-glucosidase was determined as described by Kazeem et al. (2013) using $\alpha$-glucosidase enzyme derived from Saccharomyces cerevisiae. Aliquot of $100 \mu \mathrm{L}$ of $\alpha$-glucosidase (1.0 U/mL, Sigma, St. Louis, USA) was preincubated with $50 \mu \mathrm{L}$ of seaweed extracts at different concentrations for $10 \mathrm{~min}$. Then, $50 \mu \mathrm{L}$ of $3.0 \mathrm{mM}$-nitrophenyl glucopyranoside (pNPG) (Sigma, St. Louis, USA) as a substrate dissolved in $20 \mathrm{mM}$ phosphate buffer ( $\mathrm{pH}$ 6.9) was added to begin the reaction. The reaction mixture was incubated at $37^{\circ} \mathrm{C}$ for $20 \mathrm{~min}$ then stopped by adding $2 \mathrm{ml}$ of $0.1 \mathrm{M} \mathrm{Na}_{2} \mathrm{CO}_{3}$ solution. The $\alpha$-glucosidase activity was determined by measuring the yellow-colored $p$-nitrophenol released from pNPG at $405 \mathrm{~nm}$ on a spectrophotometer. The results were expressed as inhibition percentage of the blank control as (Kazeem et al., 2013):

$$
\% \text { Inhibition }=\frac{\text { Absorbance of control }- \text { Absorbance of extract }}{\text { Absorbance of control }} \times 100
$$

Concentrations of the most promising extract resulting in $50 \%$ inhibition of the enzyme activity $\left(\mathrm{IC}_{50}\right)$ were determined by GraphPad prism 6 software

\subsection{Cytotoxicity (MTT) assay}

This assay was performed according to Kohler et al. (2005) procedures. A human prostatic stromal myofibroblast normal cell line (WPMY-1) was maintained in a standard medium consisting of DEMEM (Dulbecco's Modified Eagle Medium) with $10 \%$ $(\mathrm{v} / \mathrm{v})$ fetal bovine serum and $1 \%(\mathrm{v} / \mathrm{v})$ penicillin/streptomycin and incubated at $37^{\circ} \mathrm{C}$ in a $5 \% \mathrm{CO}_{2}$ prior to use. Then, cells were seeded into 96 -well cell culture plates at a concentration of
$1 \times 10^{4}$ cells $/ \mathrm{mL}$ and incubated for $24 \mathrm{~h}$ at standard condition. After that, cells were treated with different concentration (250 to $1000 \mu \mathrm{g} / \mathrm{mL}$ ) of T. decurrens acetone extract. After $48 \mathrm{~h}$ incubation period, the medium was removed and $5 \mathrm{mg} / \mathrm{mL}$ of MTT reagent was added to each well and re-incubated for 3-4 h. The developed formazan crystals were dissolved in $100 \mu \mathrm{L}$ acidified isopropanol and measured at $630 \mathrm{~nm}$ using ELISA microplate reader (Bio-Rad micro plate reader, Japan). Each concentration was repeated in triplicates and cell viability was calculated as (Kohler et al., 2005):

$$
\text { Cell viability }(\%)=\left(1-\frac{\text { Absorbance of control }- \text { Absorbance of extract }}{\text { Absorbance of control }}\right) \times 100
$$

\subsection{Gas chromatography-mass spectrum (GC-MS) analysis of Turbinaria decurrens acetone extract}

T. decurrens acetone extract was subjected to GC-MS Spectrometer (Perkin Elmer model: Clarus 580/560 S) for identification of its different components. GC-MS analysis was performed by injecting $1 \mu \mathrm{L}$ of sample on the column (Rxi-5Sil MS column 30m, 0.25mmID, $0.25 \mathrm{df}$ ) under Helium as carrier gas. Oven temperature was programed as: initial temp. $50^{\circ} \mathrm{C}$ for $2.50 \mathrm{~min}, 8^{\circ} \mathrm{C} / \mathrm{min}$ to $250{ }^{\circ} \mathrm{C}$, hold $5 \mathrm{~min}, 5^{\circ} \mathrm{C} / \mathrm{min}$ to $280^{\circ} \mathrm{C}$, hold $2 \mathrm{~min}$; injector temp.: $280{ }^{\circ} \mathrm{C}$, with solvent delay time: 4.00 min. Transfer temp.: $280^{\circ} \mathrm{C}$; source temp.: $200{ }^{\circ} \mathrm{C}$; split ratio: 20:1; scan: 50 to $600 \mathrm{Da}$. The identification of components was based on comparing their mass spectra with the database of the National Institute Standard and Technology (NIST) software applied to the GC-MS instrument.

\subsection{Statistical analysis}

Statistical analysis was performed using two-way ANOVA (SPSS 25, 2017) software and all the results were expressed as mean \pm standard deviation $(n=3)$.

\section{Results and discussion}

\subsection{Identification of the collected seaweeds}

Collected seaweed species were identified to be: Turbinaria decurrens (Bory), Padina pavonica (Linnaeus) Thivy, Sargassum muticum (Yendo) Fensholt and Sargassum acinarium (Linnaeus) Setchell (as Phaeophyta); Ulva lactuca Linnaeus (as Chlorophyta) and Pterocladia capillacea (Gmelin) Barnet et Thuret (as Rhodophyta) (Figure 1).

\subsection{Phytochemical analysis of different seaweed extracts}

Phytochemical analysis of different seaweed extracts (Table 1) showed presence of carbohydrates and valuable secondary metabolites such as phenols, flavonoids, alkaloids, terpenoids, steroid and glycosides in nearly all tested extracts. Meanwhile, tannins and saponins were rarely detected. Presence of these compounds were apparently dependent on the solvent and the tested seaweed species.

The presence of these bioactive compounds in the various extracts might be responsible for their biological activities as being acted synergistically to pursue antioxidant and antidiabetic 


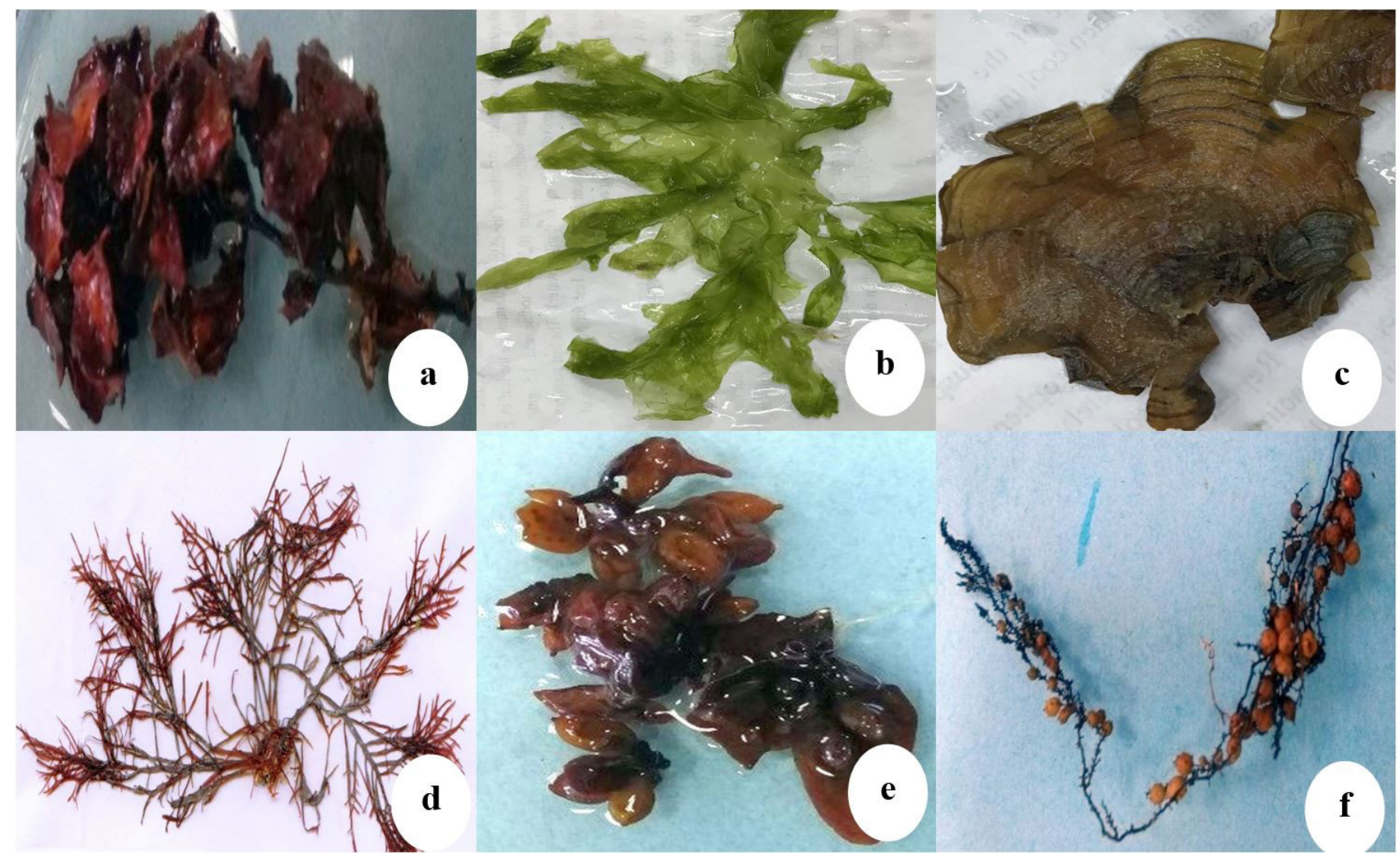

Figure 1. Photos of the studied seaweeds (a) Turbinaria decurrens (b) Ulva lactuca (c) Padina pavonica (d) Pterocladia capillacea (e) Sargassum muticum (f) Sargassum acinarium (Taken by Omnia Abdel-Karim).

Table 1. Qualitative phytochemicals screening of different seaweed extracts.

\begin{tabular}{|c|c|c|c|c|c|c|c|c|c|c|c|c|c|c|c|c|c|c|c|c|c|c|c|c|}
\hline \multirow{2}{*}{$\begin{array}{c}\text { Seaweed } \\
\text { Phytochemicals/solvents } \\
\end{array}$} & \multicolumn{4}{|c|}{ T. decurrens } & \multicolumn{4}{|c|}{ P. pavonica } & \multicolumn{4}{|c|}{ S. muticum } & \multicolumn{4}{|c|}{ S. acinarium } & \multicolumn{4}{|c|}{ U. lactuca } & \multicolumn{4}{|c|}{ P. capillacea } \\
\hline & W & $\mathrm{A}$ & $\mathrm{E}$ & $\mathrm{M}$ & $\mathrm{W}$ & A & $\mathrm{E}$ & $\mathrm{M}$ & W & A & $\mathrm{E}$ & $\mathrm{M}$ & W & A & $\mathrm{E}$ & $\mathrm{M}$ & $\mathrm{W}$ & A & $\mathrm{E}$ & $\mathrm{M}$ & W & $\mathrm{A}$ & $\mathrm{E}$ & $\mathrm{M}$ \\
\hline Alkaloid & + & + & + & + & + & + & + & 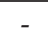 & + & + & + & + & + & + & + & + & - & + & - & + & + & + & + & + \\
\hline Phenols & + & + & + & + & + & + & + & + & + & + & + & + & + & + & + & + & + & + & + & + & + & + & + & + \\
\hline Flavonoids & + & + & + & + & + & + & + & + & - & + & + & + & - & + & + & + & + & + & + & + & + & + & + & + \\
\hline Carbohydrat & + & + & + & + & + & + & + & + & + & + & + & + & + & + & + & + & + & - & - & + & + & + & + & + \\
\hline Tannins & + & - & - & - & - & - & - & + & + & - & - & - & + & - & - & - & + & + & - & - & + & + & - & - \\
\hline Glycoside & - & + & + & + & + & + & + & + & - & - & + & + & - & - & + & - & + & + & + & + & + & - & - & - \\
\hline Saponins & - & - & - & - & - & - & - & - & - & - & - & - & - & - & - & - & - & - & + & + & + & + & + & - \\
\hline Steroid & + & + & + & + & + & + & + & + & + & + & + & + & + & + & + & + & + & + & + & + & + & + & + & + \\
\hline Terpenoids & + & + & + & + & + & + & + & + & + & + & + & + & + & + & + & + & + & + & + & + & + & + & + & + \\
\hline
\end{tabular}

Abbreviations: W: water; A: acetone; E: ethanol; M: Methanol; +: present, -: absent.

functions. Similar compounds were reported from Gracilaria verrucosa, Enteromorpha compressa, Ulva fasciata and Turbinaria conoides extracts (Mohapatra et al., 2016). Different extracts of Jania rubens, Corallina mediterranea and Pterocladia capillacea exhibited several biological activities as antimicrobial and antioxidant activities as have been reported by Mohy El-Din \& El-Ahwany (2018).

\subsection{Antioxidant assays}

The antioxidant potential of different seaweeds with diverse solvents was studied through its scavenging ability of the DPPH radical. Most of the tested seaweed extracts were able to reduce the steady DPPH radical to the yellow colored diphenylpricrylhydrazine depending on the solvent and species. The acetone extract of T. decurrens exhibited the highest DPPH scavenging activity of $61.6 \%$; followed by the water extract of P. pavonica with $55.2 \%$ inhibition capacity. Likewise, the ethanol extract of S. muticum and S. acinarium showed significant inhibition activity with $53.89 \%$ and $49.42 \%$, respectively (Figure 2). The $\mathrm{IC}_{50}$ value recorded $40.66 \mathrm{mg} / \mathrm{mL}$ for the acetone extract of T. decurrens which was comparable to the estimated $\mathrm{IC}_{50}$ value of ascorbic acid $5.21 \mathrm{mg} / \mathrm{mL}$. In accordance with these results Unnikrishnan et al. (2014) reported the scavenging activity of Turbinaria oranta acetone extract against DPPH with 65\%. Aqueous extracts of Cystoseira crinita and Cystoseira compressa 
(Mhadhebi et al., 2014) and ethyl acetate extract of Anthophycus longifolius (Chakraborty et al., 2017) exhibited an excellent scavenging activity against DPPH radical estimated as $\mathrm{IC}_{50}$ value. Also, the acetone extract of Sargassum wightii and the benzene extract of Sargassum polycystum exhibited DPPH antioxidant activity with $43 \%$ and $22 \%$, respectively (Unnikrishnan et al., 2015). In a recent study, the Celluclast (a preparation used to degrade cellulose into glucose) enzymatic extract of Sargassum polycystum revealed a strong DPPH scavenging activity estimated to be $57.23 \%$ (Shanura Fernando et al., 2018).

As shown in (Table 2), acetone extract of the tested $T$. decurrens and water extract of $P$. pavonica showed the highest reducing ability of 2.72 and $1.58 \mathrm{mg} \mathrm{AAE} / \mathrm{g}$ DW, respectively followed by the ethanol extract of $S$. muticum and S. acinarium with 1.37 and $1.34 \mathrm{mg} \mathrm{AAE} / \mathrm{g} \mathrm{DW}$, respectively. However, the methanolic extracts recorded the lowest reducing activity compared to the other extracts.

Results in (Table 2) showed that in the total antioxidant capacity assay, all seaweeds presented significant (at $P \leq 0.05$ ) antioxidant activity using different solvents. The acetone extract of $T$. decurrens recorded the maximum activity of $4.3 \mathrm{mg} \mathrm{AAE} / \mathrm{g}$ DW. Also, the water extract of P. pavonica and the ethanol extract of $S$. muticum showed significant potent activity with 3.26 and $3.09 \mathrm{mg} \mathrm{AAE} / \mathrm{g}$ DW, respectively. On the contrary, the methanol extract of T. decurrens gave the lowest result with $0.52 \mathrm{mg} \mathrm{AAE} / \mathrm{g}$ DW. The antioxidant activity of these seaweeds might be due to their ability to act as free radicals' scavengers or by providing a hydrogen atom to the molecule (Boonchum et al., 2011). The obtained results were in accordance with those reported by Mohy El-Din \& El-Ahwany (2018) for the reducing power and total antioxidant capacity of Pterocladia capillacea methanolic extract with recorded values of 4.007 and $0.940 \mathrm{mg} \mathrm{AAE} / \mathrm{g}$ DW, respectively.

\subsection{Total Phenolic Content (TPC)}

The total phenolic contents of various tested seaweed extracts ranged from 0.38 to $4.32 \mathrm{mg} \mathrm{GAE} / \mathrm{g}$ DW (Figure 3). The acetone extract of $T$. decurrens exhibited the highest phenolic content value of $4.32 \mathrm{mg} \mathrm{GAE} / \mathrm{g}$ DW followed by the water extract of $P$. pavonica, while the ethanol extract of $S$. muticum and $S$. acinarium recorded close total phenolic contents values with 3.31 and $2.88 \mathrm{mg} \mathrm{GAE} / \mathrm{g}$ DW, respectively. Collectively, the correlation between total phenolic content of different extracts and their antioxidant activity was evident as shown in (Table 3), especially for T. decurrens, P. pavonica and S. muticum seaweed extracts, respectively. The findings reported by Wang et al. (2009) confirmed that amounts of polyphenols in brown seaweeds were higher than that in red and green ones and might be the reason

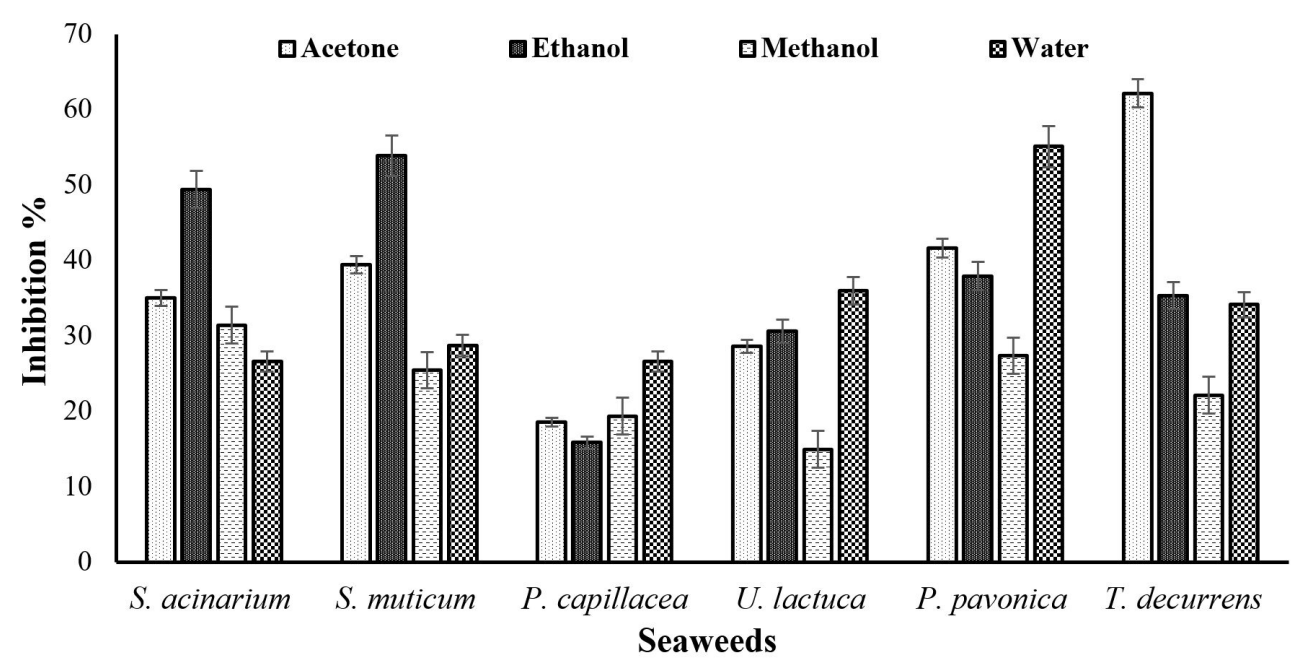

Figure 2. DPPH radical scavenging activity of different seaweed extracts.

Table 2. Total Antioxidant capacity and reducing power activity in the studied seaweeds.

\begin{tabular}{|c|c|c|c|c|c|c|c|c|}
\hline \multirow{3}{*}{$\begin{array}{c}\text { Assay } \\
\text { Seaweed }\end{array}$} & \multicolumn{4}{|c|}{ Total Antioxidant Capacity (mg AAE/g DW) } & \multicolumn{4}{|c|}{ Reducing Power Activity (mg AAE/g DW) } \\
\hline & \multicolumn{8}{|c|}{ Extract } \\
\hline & Acetone & Ethanol & Methanol & Water & Acetone & Ethanol & Methanol & Water \\
\hline S. acinarium & $1.68^{\mathrm{a}, \mathrm{A}} \pm 0.006$ & $.76^{\mathrm{a}, \mathrm{B}} \pm 0.015$ & $2.10^{\mathrm{a}, \mathrm{C}} \pm 0.008$ & $0.71^{\mathrm{a}, \mathrm{D}} \pm 0.003$ & $0.35^{\mathrm{a}, \mathrm{A}} \pm 0.021$ & $1.34^{\mathrm{a}, \mathrm{B}} \pm 0.099$ & $0.36^{\mathrm{a}, \mathrm{A}} \pm 0.027$ & $0.52^{\mathrm{a}, \mathrm{A}} \pm 0.005$ \\
\hline S. muticum & $2.29^{\mathrm{b}, \mathrm{A}} \pm 0.007$ & $3.09^{\mathrm{b}, \mathrm{B}} \pm 0.022$ & $0.86^{\mathrm{b}, \mathrm{C}} \pm 0.002$ & $0.67^{\mathrm{b}, \mathrm{D}} \pm 0.003$ & $0.96^{\mathrm{b}, \mathrm{A}} \pm 0.008$ & $1.37^{\mathrm{a}, \mathrm{B}} \pm 0.010$ & $0.24^{\mathrm{b}, \mathrm{C}} \pm 0.014$ & $0.71^{\mathrm{b}, \mathrm{D}} \pm 0.009$ \\
\hline P. capillacea & $1.01^{\mathrm{c}, \mathrm{A}} \pm 0.001$ & $0.86^{\mathrm{c}, \mathrm{B}} \pm 0.002$ & $0.79^{c, \mathrm{C}} \pm 0.001$ & $0.98^{\mathrm{c}, \mathrm{D}} \pm 0.002$ & $0.25^{\mathrm{c}, \mathrm{A}} \pm 0.013$ & $0.27^{\mathrm{c}, \mathrm{A}} \pm 0.001$ & $0.16^{\mathrm{c}, \mathrm{B}} \pm 0.009$ & $0.65^{\mathrm{c}, \mathrm{C}} \pm 0.019$ \\
\hline U. lactuca & $1.17^{\mathrm{d}, \mathrm{A}} \pm 0.004$ & $1.08^{\mathrm{d}, \mathrm{B}} \pm 0.003$ & $1.01^{\mathrm{d}, \mathrm{C}} \pm 0.001$ & $1.18^{\mathrm{d}, \mathrm{A}} \pm 0.004$ & $0.36^{\mathrm{d}, \mathrm{A}} \pm 0.018$ & $0.45^{\mathrm{d}, \mathrm{B}} \pm 0.009$ & $0.24^{\mathrm{b}, \mathrm{C}} \pm 0.006$ & $0.71^{\mathrm{ce}, \mathrm{D}} \pm 0.016$ \\
\hline P. pavonica & $2.50^{\mathrm{e}, \mathrm{A}} \pm 0.074$ & $1.17^{\mathrm{e}, \mathrm{B}} \pm 0.038$ & $1.13^{\mathrm{e}, \mathrm{B}} \pm 0.034$ & $3.26^{\mathrm{e}, \mathrm{C}} \pm 0.010$ & $0.85^{\mathrm{d}, \mathrm{A}} \pm 0.026$ & $0.68^{\mathrm{e}, \mathrm{B}} \pm 0.02$ & $0.67^{\mathrm{d}, \mathrm{C}} \pm 0.013$ & $1.58^{\mathrm{e}, \mathrm{D}} \pm 0.097$ \\
\hline T. decurrens & $4.34^{\mathrm{f}, \mathrm{A}} \pm 0.003$ & $0.58^{\mathrm{f}, \mathrm{B}} \pm 0.002$ & $0.52^{\mathrm{f}, \mathrm{C}} \pm 0.002$ & $1.19^{\mathrm{d}, \mathrm{D}} \pm 0.002$ & $2.72^{\mathrm{e}, \mathrm{A}} \pm 0.014$ & $0.48^{\mathrm{d}, \mathrm{B}} \pm 0.005$ & $0.32^{\mathrm{a}, \mathrm{C}} \pm 0.017$ & $0.75^{\mathrm{d}, \mathrm{D}} \pm 0.020$ \\
\hline
\end{tabular}

Values were mean \pm SD of three replicates $(n=3)$. Small Values in the same column with different small superscripts are significantly different, and capital values in the same row with different capital superscripts are significantly different at $p \leq 0.05$ in the two-sided test of equality for row means. 


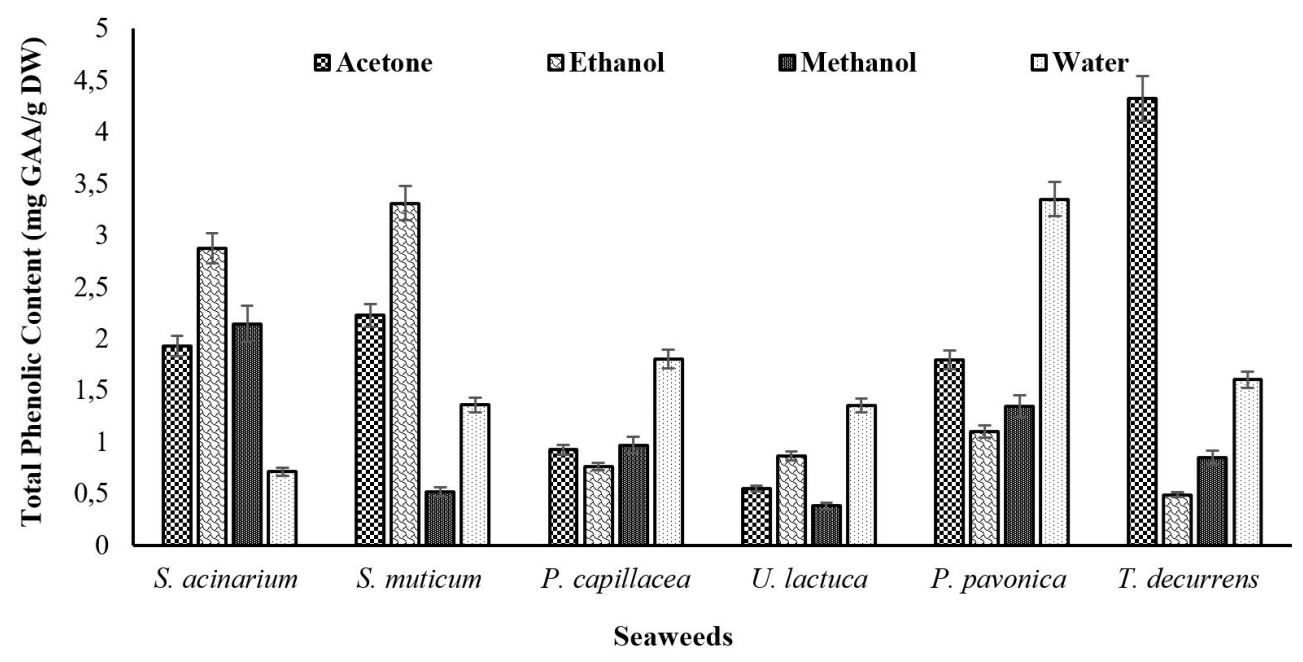

Figure 3. Total phenolic content of different seaweed extracts.

Table 3. Correlation values between total phenolic content and antioxidant activity in different seaweeds.

\begin{tabular}{lcccccc}
\hline \multirow{2}{*}{ Algal extract / Antioxidant activities } & \multicolumn{5}{c}{ Total Phenolic content } \\
\cline { 2 - 7 } & S. acinarium & S. muticum & P. capillacea & U. lactuca & P. pavonica & T. decurrens \\
\hline DPPH radical scavenging activity & 0.890 & $0.942^{*}$ & 0.897 & 0.727 & 0.867 & $0.981^{*}$ \\
Reducing Power Activity & 0.738 & $0.990^{*}$ & $0.951^{*}$ & 0.876 & $0.983^{*}$ & $0.993^{*}$ \\
Total Antioxidant Capacity & 0.931 & 0.935 & $0.981^{*}$ & $0.969^{*}$ & 0.919 & $0.988^{*}$ \\
\hline
\end{tabular}

${ }^{*}$ Correlation is significant $p \leq 0.05$.

of their antioxidant activity. In addition, phenolic compounds were ordinarily found in brown, red and green seaweeds and could act as antioxidants by chelating metal ions, hindering radical formation and stimulating the endogenous defense system of antioxidant (Al-Azzawie \& Alhamdani, 2006). Our results also indicated a strong correlation (at $P \leq 0.05$ ) between the antioxidant activity using DPPH, reducing power and TAC with the estimated total phenolic content of seaweeds which were in adherence to studies by Ismail et al. (2016) and Ismail (2017). In addition, some studies reported the antioxidant activities of the seaweeds are associated with the phenolic algal content (Shanura Fernando et al., 2018). Nowadays, there is a growing concern on the discovery of natural antioxidants mainly because biologically active phytochemicals are largely more secure than manufactured synthetic analogies and for their conservative role in the improvement of disease like cancer, atherosclerosis, arthritis, diabetes, alzheimer's and aging (Santos-Sánchez et al., 2019).

\subsection{Antidiabetic assay}

One of the most effective ways for treating diabetic patients is by controlling of postprandial hyperglycemia. This can be done by inhibiting the hydrolyzing enzymes of carbohydrate in the digestive system such as $\alpha$-amylase and $\alpha$-glucosidase, thus decreasing the absorption of glucose (Pirian et al., 2017). The inhibitory effect of seaweed extracts using different solvents were assayed for $\alpha$-amylase enzyme (Figure 4 ). All tested extracts showed significant (at $P \leq 0.05) \alpha$-amylase inhibition activity depending on the solvent. Organic solvents were of pronounced effect than aqueous solvent. The acetone extract of T. decurrens was of the maximum inhibition capacity recording $96.1 \%$ with an $\mathrm{IC}_{50}$ value of $4.37 \mathrm{mg} / \mathrm{ml}$ compared to positive control (Acarbose) with $1.59 \mathrm{mg} / \mathrm{ml}$ followed by the ethanol extract of S. muticum with an inhibition activity of $94.3 \%$. Similarly, the ethanol extract of S. acinarium presented $91.8 \%$ inhibition of a-amylase enzyme.

$p$-nitrophenyl $\alpha$-D-glucopyranoside compound was used as a substrate to determine the inhibitory activity of different seaweed extracts on $\alpha$-glucosidase enzyme (Figure 5). The acetone and ethanol extracts were significantly effective. At a concentration of $90 \mathrm{mg} / \mathrm{mL}$, the acetone extract of $T$. decurrens showed the maximum inhibition record of $97.4 \%$ with an $\mathrm{IC}_{50}$ value of $2.84 \mathrm{mg} / \mathrm{mL}$, while acarbose, which considered to be positive control, was with an $\mathrm{IC}_{50}$ value of $1.03 \mathrm{mg} / \mathrm{ml}$. Similar findings were found by Unnikrishnan et al. (2014) who reported that Turbinaria oranta in acetone showed the highest $\alpha$-glucosidase inhibition activity (87.6\%), while the same seaweed methanol extract recorded the maximum percentage inhibition on $\alpha$-amylase (96.5\%). In addition, the percentage inhibition and $\mathrm{IC}_{50}$ values showed that the acetone extract of T. decurrens was an effective inhibitor for both carbohydrate analyzing $\alpha$-amylase and a-glucosidase enzymes and thus played a key role in controlling of postprandial hyperglycemia. Furthermore, many studies reported the feasibility of brown seaweed extracts such as Ishige okamurae and different Sargassum spp. as antidiabetic agents and their potent activity as an inhibitor of $\alpha$-glucosidase and $\alpha$-amylase (Lee \& Han, 2012; Unnikrishnan et al., 2015; Yang et al., 2019). However, moderate inhibition of $\alpha$-amylase may be preferable to avoid side effects that can be appear by the abnormal bacteria 


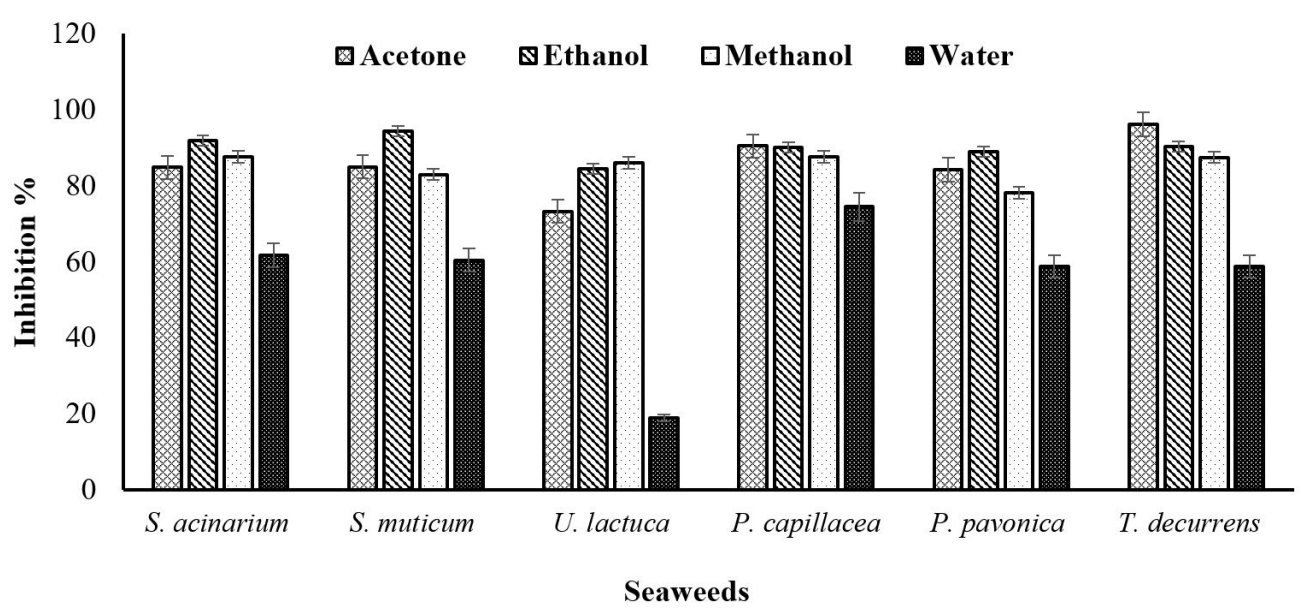

Figure 4. In vitro a-amylase inhibitory activity (at $540 \mathrm{~nm}$ ) of different seaweed extracts.

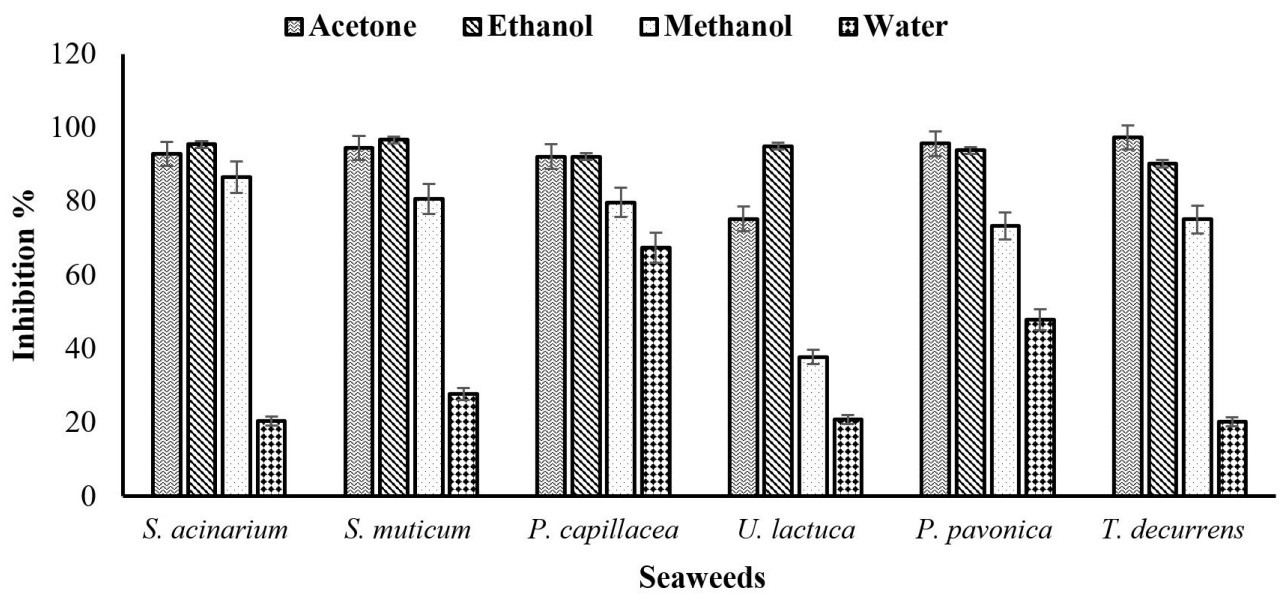

Figure 5. In Vitro a-glucosidase inhibitory activity (at $405 \mathrm{~nm}$ ) of different seaweeds extracts.

in the colon due to fermentation (Lordan et al., 2013). Disposed that acetone extract of T. decurrens has stronger inhibitory effect against $\alpha$-glucosidase than $\alpha$-amylase enzyme, implying a potent effective medication for treatment of postprandial hyperglycemia with low side effects. According to Apostolidis et al. (2011); Nwosu et al. (2011) and Pirian et al. (2017), the antidiabetic activity of seaweeds might be due to the presence of different phytochemical compounds such as polyphenols which bind to the active sites of the diabetic enzymes and alter their catalytic activity, so that correlated to the antioxidant activity. The same correlation was observed in this study where the acetone extract of $T$. decurrens had the highest phenolic content between the other tested seaweeds.

\subsection{Cytotoxicity assay}

The cytotoxic effect of $T$. decurrens acetone extract at different concentrations on WPMY-1 normal cell line was shown in Figure 6 at 24 and 48 hours. By increasing the concentration, the cell inhibition percentage increased too. At lower concentrations of $250 \mu \mathrm{g} / \mathrm{mL}, 97.62 \%$ and $96.18 \%$ of cell viability was recorded at 24 and 48 hours of incubation, respectively. The recorded values for the extract were above the maximum tested concentration
$(1000 \mu \mathrm{g} / \mathrm{mL})$ that supporting the safety of the extract. The obtained results were in contract with Unnikrishnan et al. (2014) who reported the safety of Turbinaria oranta acetone extract on J774 cell line at lower concentrations.

\subsection{GC-MS analysis of T. decurrens acetone extract}

GC/MS analysis of T. decurrens acetone extract identified different compounds (Figure 7) which might be responsible for its hypoglycemic properties. The major bioactive compounds and their bioactive properties were listed in Table 4 . The cyclic, unsaturated cyclotrisiloxane, hexamethyl (23.002\%) has been reported as antimicrobial agents (Keskin et al., 2012), antibacterial activity (Musini et al., 2013) and antioxidant activity and play a critical role in scavenging of free radicals (Prakash \& Vuppu, 2014). The a cyclic diterpene 3,7,11,15-tetramethyl-2-hexadecen-1-ol (known as phytol alcohol) (15.42\%) has been known to act as a good preventive for the reactive oxygen species and as precursor for vitamin E and vitamin K1 (Ganesh \& Mohankumar, 2017), as antimicrobial, diuretic, and chemo-preventive properties and was used in vaccine formulations (Krishnamoorthy \& Subramaniam, 2014) as well as anti-cancer properties (Gautam et al., 2018), o-Xylene (12.251\%), and cyclotetrasiloxane, octamethyl (6.625\%) 


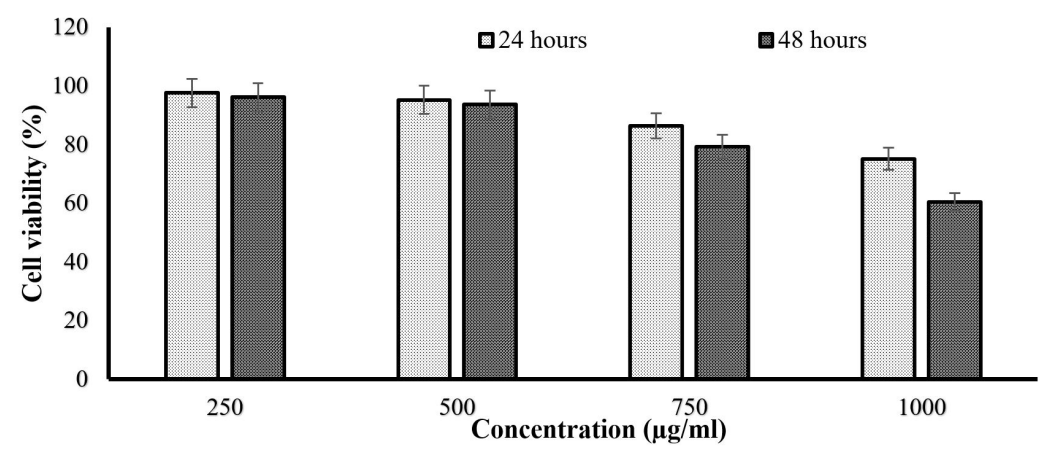

Figure 6. Cytotoxicity on WPMY-1 normal cell line treated with different concentrations of acetone extract of Turbinaria decurrens.

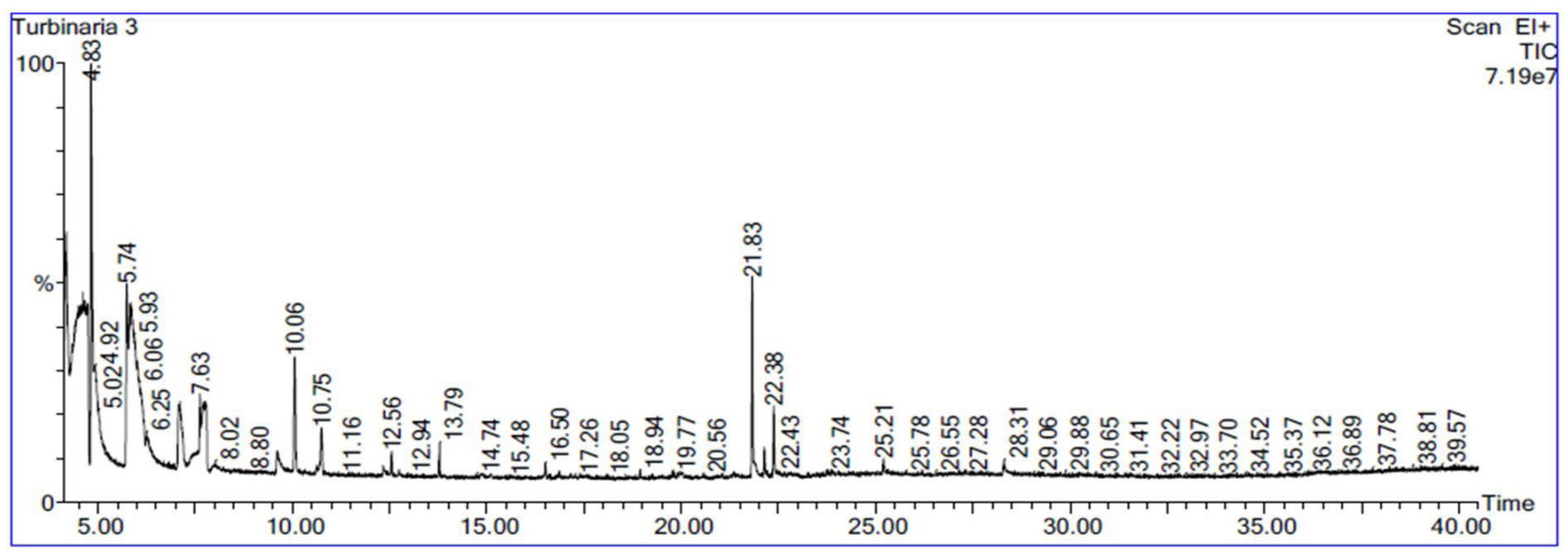

Figure 7. GC-MS chromatogram of Turbinaria decurrens acetone extract.

Table 4. GC-MS analysis of the acetone extract of Turbinaria decurrens.

\begin{tabular}{|c|c|c|c|c|}
\hline $\mathrm{RT}^{\star}$ & Compounds name & $\mathrm{PA}^{*} \%$ & $\mathrm{MF}^{*}$ & Biological activity \\
\hline 4.188 & Cyclotrisiloxane, hexamethyl & 20.42 & $\mathrm{C}_{6} \mathrm{H}_{18} \mathrm{O}_{3} \mathrm{Si}_{3}$ & Antimicrobial, antioxidant, antibacterial \\
\hline 4.619 & Cyclotrisiloxane, hexamethyl & 100 & $\mathrm{C}_{6} \mathrm{H}_{18} \mathrm{O}_{3} \mathrm{Si}_{3}$ & As mentioned \\
\hline 4.829 & 2-Pentanone, 4-hydroxy-4-methyl & 73.56 & $\mathrm{C}_{6} \mathrm{H}_{12} \mathrm{O}_{2}$ & A plant metabolite, solvent \\
\hline 5.744 & o-Xylene & 21.95 & $\mathrm{C}_{6} \mathrm{H}_{4}\left(\mathrm{CH}_{3}\right)_{2}$ & Antifungal, antibacterial and antioxidant \\
\hline 5.849 & o-Xylene & 94.01 & $\mathrm{C}_{6} \mathrm{H}_{4}\left(\mathrm{CH}_{3}\right)_{2}$ & As mentioned, \\
\hline 6.249 & Oxime-, methoxy-phenyl & 10.72 & $\mathrm{C}_{8} \mathrm{H}_{9} \mathrm{NO}_{2}$ & Antimicrobial, antioxidant \\
\hline 7.555 & Cyclotetrasiloxane, octamethyl & 3.19 & $\mathrm{C}_{8} \mathrm{H}_{24} \mathrm{O}_{4} \mathrm{Si}_{4}$ & As mentioned, \\
\hline 7.630 & Cyclotetrasiloxane, octamethyl & 8.79 & $\mathrm{C}_{8} \mathrm{H}_{24} \mathrm{O}_{4} \mathrm{Si}_{4}$ & As mentioned, \\
\hline 7.770 & Cyclotetrasiloxane, octamethyl & 19.07 & $\mathrm{C}_{8} \mathrm{H}_{24} \mathrm{O}_{4} \mathrm{Si}_{4}$ & As mentioned, \\
\hline 7.990 & Benzene, 1,2,3-trimethyl & 1.21 & $\mathrm{C}_{9} \mathrm{H}_{12}$ & ---- \\
\hline 9.611 & Cyclotrisiloxane, hexamethyl & 5.10 & $\mathrm{C}_{6} \mathrm{H}_{18} \mathrm{O}_{3} \mathrm{Si}_{3}$ & Antimicrobial, antioxidant, antibacterial \\
\hline 12.557 & $\begin{array}{l}\text { 1,1,1,3,5,7,9,11,11,11-Decamethyl-5- } \\
\text { (trimethylsiloxy) hexasiloxane }\end{array}$ & 1.47 & & ----- \\
\hline 13.787 & Cyclohexasiloxane, dodecamethyl & 2.06 & $\mathrm{C}_{12} \mathrm{H}_{36} \mathrm{O}_{6} \mathrm{Si}_{6}$ & Antimicrobial, antioxidant, antibacterial \\
\hline 16.513 & Cyclotetrasiloxane, octamethyl- & 1.39 & $\mathrm{C}_{8} \mathrm{H}_{24} \mathrm{O}_{4} \mathrm{Si}_{4}$ & As mentioned \\
\hline 21.831 & 3,7,11,15-Tetramethyl-2-hexadecen-1-ol & 15.42 & $\mathrm{C}_{20} \mathrm{H}_{40} \mathrm{O}$ & Anti-inflammatory, antioxidant, antimicrobial, anticancer, anti-diuretic \\
\hline 22.146 & 3,7,11,15-Tetramethyl-2-hexadecen-1-ol & 2.27 & $\mathrm{C}_{20} \mathrm{H}_{40} \mathrm{O}$ & As mentioned, \\
\hline 22.381 & 3,7,11,15-Tetramethyl-2-hexadecen-1-ol & 5.56 & $\mathrm{C}_{20} \mathrm{H}_{40} \mathrm{O}$ & As mentioned, \\
\hline 25.207 & 3,7,11,15-Tetramethyl-2-hexadecen-1-ol & 1.44 & $\mathrm{C}_{20} \mathrm{H}_{40} \mathrm{O}$ & As mentioned, \\
\hline
\end{tabular}

${ }^{*}$ RT: Retention Time; ${ }^{*}$ PA: Peak Area; ${ }^{\star}$ MF: Molecular Formula. 
were known for their antifungal, antibacterial and antioxidant activity (Rizwana et al., 2016), Oxime-, methoxy-phenyl (1.964\%) has been reported for its antimicrobial (Patil et al., 2012) and antioxidant properties (Özen \& Taş, 2009). Although there was no information confirming the presence of antidiabetic effects of any of the previously mentioned compounds, but still they may act synergistically to exert the estimated significant inhibition of diabetic enzymes. The over-production of reactive oxygen species or impaired antioxidant defense system resulted in diabetes which leads to oxidative damage of $\beta$-cells of pancreas (Baynes, 2003). A lot of reports detected that reactive oxygen species (ROS) led to several diseases including diabetes; thus, involving efficient quantities of antioxidant compounds in dietary meals may be valuable in controlling diabetic complications (Mohapatra et al., 2016). In this connection, marine seaweeds are great provenance of dietary fibers, polysaccharides, polyphenols, polyunsaturated fatty acids, minerals, and vitamins which have different biological activities like antidiabetic, anti-inflammatory and antioxidant activity (Ismail et al., 2016; Ismail, 2017; Yang et al., 2019).

\section{Conclusion}

In this study different organic and water extracts of six studied seaweeds belonging to different divisions showed great variation in their antioxidant potential particularly in acetone, water and ethanol extracts. This antioxidant capacity was significantly correlated to their phenolic content, especially for the brown seaweeds: T. decurrens, P. pavonica, S. muticum and $S$. acinarium These seaweeds were also exhibited a potent inhibitory activity, in vitro, on $\alpha$-amylase and $\alpha$-glucosidase starch hydrolyzing enzymes. The acetone extract of $T$. decurrens showed maximum inhibitory activity combined with a highest antioxidant capacity. In vitro toxicological parameter indicated that $T$. decurrens acetone extract was greatly below the cytotoxicity levels. The GC/MS analysis confirmed the presence of bioactive compounds responsible for the antioxidant and antidiabetic activities which recommended this extract ingredients for suppressing hyperglycemia. In vivo future studies are in need to evaluate the feasibility of $T$. decurrens extract for developing potent antioxidant and/or antidiabetic drugs.

\section{Acknowledgements}

The authors would like to express their gratitude and appreciation to Prof. Mona Ismail National Institute of Oceanography and Fisheries | NIOF Division of Marine Environment, Kayet Bay, Alexandria,21556, Egypt, for her scientific assistance in the identification and authentication of the different seaweed samples. Also, thankfulness and appreciation extended to Dr. Mohamed Zakaria Hatim, Assistant lecturer of Ecology, Botany and Microbiology Department, Faculty of Science, Tanta University, Egypt for his valuable assistance in the statistical analysis of this work.

\section{References}

Ahmed, D., Baig, H., \& Zara, S. (2013). Seasonal variation of phenolics, flavonoids, antioxidant and lipid peroxidation inhibitory activity of methanolic extract of Melilotus indicus and its sub-fractions in different solvents. International Journal of Phytomedicine, 4(3), 326-333.
Akpaso, M. I., Igiri, A. O., \& Odey, P. A. (2017). A comparative study on the effect of combined methanolic leaf extracts of Vernonia amygdalina and Gongronema latifolium and metformin on the pancreatic beta cells of streptozotocin induced diabetic wister rats. Asian Journal of Pharmacy, Nursing and Medical Sciences, 5(2), 4248. http://dx.doi.org/10.24203/ajpnms.v5i2.4591.

Al-Azzawie, H. F., \& Alhamdani, M.-S. S. (2006). Hypoglycemic and antioxidant effect of Oleuropein in alloxan-diabetic rabbits. Life Sciences, 78(12), 1371-1377. http://dx.doi.org/10.1016/j.lfs.2005.07.029. PMid:16236331.

Aleem, A. A. (1993). The marine algae of Alexandria, Egypt. Alexandria: Faculty of Science, University of Alexandria.

American Diabetes Association - ADA. (2014). Diagnosis and classification of diabetes mellitus. Diabetes Care, 37(Suppl. 1), S81-S90. http:// dx.doi.org/10.2337/dc14-S081. PMid:24357215.

Andima, M., Bernard, S., Owor, R. \& Edward, A. (2014). Preliminary qualitative analysis of phytochemical constituents of the Endemic Aloe tororoana Raynolds in Tororo, Eastern Uganda. Global Advanced Research Journal of Agricultural Science, 3(3), 96-99.

Apostolidis, E., Karayannakidis, P. D., Kwon, Y.-I., Lee, C. M., \& Seeram, N. P. (2011). Seasonal variation of phenolic antioxidant-mediated a-glucosidase inhibition of Ascophyllum nodosum. Plant Foods for Human Nutrition, 66(4), 313-319. http://dx.doi.org/10.1007/ s11130-011-0250-4. PMid:21842257.

Baynes, J. W. (2003). Chemical modification of proteins by lipids in diabetes. Clinical chemistry and laboratory medicine, 41(9):1159-65.

Boonchum, W., Peerapornpisal, Y., Kanjanapothi, D., \& Pekkoh, J. (2011). Antioxidant activity of some seaweed from the Gulf of Thailand. International Journal of Agriculture and Biology, 13, 95-99.

Chakraborty, K., Maneesh, A., \& Makkar, F. (2017). Antioxidant activity of brown seaweeds. Journal of Aquatic Food Product Technology, 26(4), 406-419. http://dx.doi.org/10.1080/10498850.2016.1201711.

Cox, S., Abu-Ghannam, N., \& Gupta, S. (2010). An assessment of the antioxidant and antimicrobial activity of six species of edible Irish seaweeds. International Food Research Journal, 17, 205-220.

Ganesh, M., \& Mohankumar, M. (2017). Extraction and identification of bioactive components in Sida cordata (Burm.f.) using gas chromatography-mass spectrometry. Journal of Food Science and Technology, 54(10), 3082-3091. http://dx.doi.org/10.1007/s13197017-2744-z. PMid:28974793.

Gautam, V., Kohli, S. K., Arora, S., Bhardwaj, R., Kazi, M., Ahmad, A., Raish, M., Ganaie, M. A., \& Ahmad, P. (2018). Antioxidant and antimutagenic activities of different fractions from the leaves of Rhododendron arboreum Sm. and their GC-MS profiling. Molecules, 23(9), 2239. http://dx.doi.org/10.3390/molecules23092239. PMid:30177614.

Guiry, M. D., \& Guiry, G. M. (2019). Algaebase, world-wide electronic publication. Galway: National University of Ireland. Retrieved from http://www.algaebase.org

Husni, A., Pawestri, S., \& Isnansetyo, A. (2016). Blood glucose level and lipid profile of alloxan-induced diabetic rats treated with $\mathrm{Na}$ alginate from seaweed Turbinaria ornata (Turner) J.agardh. Jurnal Teknologi, 78(4-2), 7-14. http://dx.doi.org/10.11113/jt.v78.8145.

Ismail, G. A. (2017). Biochemical composition of some Egyptian seaweeds with potent nutritive and antioxidant properties. Food Science and Technology, 37(2), 294-302. http://dx.doi.org/10.1590/1678-457x.20316.

Ismail, M. M., Gheda, S. F., \& Pereira, L. (2016). Variation in bioactive compounds in some seaweeds from Abo Qir bay, Alexandria, Egypt. Rendiconti Lincei, 27(2), 269-279. http://dx.doi.org/10.1007/ s12210-015-0472-8. 
Jha, B., Reddy, C. R. K., Thakur, M. C., \& Rao, M. U. (2009). The diversity and distribution of seaweeds of the Gujarat Coast. In Seaweeds of India (1. ed., pp. 215). Netherlands: Springer.

Kazeem, M. I., Adamson, J. O., \& Ogunwande, I. A. (2013). Modes of inhibition of alpha -amylase and alpha -glucosidase by aqueous extract of Morinda lucida Benth leaf. BioMed Research International, 2013, 527-570. http://dx.doi.org/10.1155/2013/527570. PMid:24455701.

Keskın, D., Ceyhan, N., Uğur, A., \& Dbeys, A. D. (2012). Antimicrobial activity and chemical constitutions of West Anatolian olive (Olea europaea L.) leaves. Journal of Food Agriculture and Environment, 10, 99-102.

Khalid, S., Abbas, M., Saeed, F., Ul Ain, H. B., \& Suleria, H. A. R. (2018). Therapeutic potential of seaweed bioactive compounds. In S. Maiti. Seaweed biomaterials (pp. 1-19). London: IntechOpen. http://dx.doi. org/10.5772/intechopen.74060.

Kohler, N., Sun, C., Wang, J., \& Zhang, M. (2005). Methotrexate-modified superparamagnetic nanoparticles and their intracellular uptake into human cancer cells. Langmuir, 21(19), 8858-8864. http://dx.doi. org/10.1021/la0503451. PMid:16142971.

Kokabi, M., Yousefzadi, M., Ali ahmadi, Feghhi, A., \& Amin, K. M. (2013). Antioxidant activity of extracts of selected algae from the Persian Gulf, Iran. Journal of the Persian Gulf, 4, 45-50.

Krishnamoorthy, K., \& Subramaniam, P. (2014). Phytochemical profiling of leaf, stem, and tuber parts of Solena amplexicaulis (Lam.) Gandhi using GC-MS. International Scholarly Research Notices, 2014, 1-13. http://dx.doi.org/10.1155/2014/567409. PMid:27379314.

Lee, C. W., \& Han, J. S. (2012). Hypoglycemic effect of Sargassum ringgoldianum extract in STZ-induced diabetic mice. Preventive Nutrition and Food Science, 17(1), 8-13. http://dx.doi.org/10.3746/ pnf.2012.17.1.008. PMid:24471057.

Lordan, S., Smyth, T. J., Soler-Vila, A., Stanton, C., \& Ross, R. P. (2013). The alpha-amylase and alpha-glucosidase inhibitory effects of Irish seaweed extracts. Food Chemistry, 141(3), 2170-2176. http://dx.doi. org/10.1016/j.foodchem.2013.04.123. PMid:23870944.

Manivannan, K., Thirumaran, G., Devi, G. K., Anantharaman, P., \& Balasubramanian, T. (2009). Proximate composition of different group of seaweeds from Vedalai Coastal Waters (Gulf of Mannar). Middle East Journal of Scientific Research, 4(2), 72-77.

Mhadhebi, L., Mhadhebi, A., Robert, J., \& Bouraoui, A. (2014). Antioxidant, anti-inflammatory and antiproliferative effects of aqueous extracts of three Mediterranean brown seaweeds of the genus Cystoseira. Iranian journal of pharmaceutical research. IJPR, 13(1), 207-220. PMid:24734073.

Mohapatra, L., Bhattamisra, S., Panigrahy, R., \& Parida, S. (2016). Evaluation of the antioxidant, hypoglycaemic and antidiabetic activities of some seaweed collected from the East Coast of India. Journal of Biomedical and Pharmacology, 9(1), 365-375. http:// dx.doi.org/10.13005/bpj/948.

Mohy El-Din, S. M., \& El-Ahwany, A. M. D. (2018). Bioactivity and phytochemical constituents of marine red seaweeds (Jania rubens, Corallina mediterranea and Pterocladia capillacea). Journal of Taibah University for Science, 10(4), 471-484. http://dx.doi.org/10.1016/j. jtusci.2015.06.004.

Musini, A., Prakash, R. M. J., \& Giri, A. (2013). Phytochemical investigations and antibacterial activity of Salacia oblonga Wall ethanolic extract. Annals of Phytomedicine, 2, 102-107.

Nwosu, F., Morris, J., Lund, V. A., Stewart, D., Ross, H. A., \& McDougall, G. J. (2011). Anti-proliferative and potential anti-diabetic effects of phenolic-rich extracts from edible marine algae. Food Chemistry, 126(3), 1006-1012. http://dx.doi.org/10.1016/j.foodchem.2010.11.111.
Özen, T., \& Taş, M. (2009). Screening and evaluation of antioxidant activity of some amido-carbonyl oxime derivatives and their radical scavenging activities. Journal of Enzyme Inhibition and Medicinal Chemistry, 24(5), 1141-1147. http://dx.doi.org/10.1080/14756360802669981. PMid:19772487.

Pamungkas, R. A., \& Chamroonsawasdi, K. (2019). HbA1c reduction and weight-loss outcomes: a systematic review and meta-analysis of community-based intervention trials among patients with type 2 diabetes mellitus. International Journal of Diabetes in Developing Countries, 39(2), 394-407. http://dx.doi.org/10.1007/s13410-0180708-0.

Patil, S. S., Jadhav, S. D., \& Deshmukh, M. B. (2012). Synthesis and antimicrobial activities of new oxime carbamates of 3-aryl-2thioquinazolin-4(3H)-one. Journal of Chemical Sciences, 124(5), 1043-1048. http://dx.doi.org/10.1007/s12039-012-0302-9.

Pirian, K., Moein, S., Sohrabipour, J., Rabiei, R., \& Blomster, J. (2017). Antidiabetic and antioxidant activities of brown and red macroalgae from the Persian Gulf. Journal of Applied Phycology, 29(6), 31513159. http://dx.doi.org/10.1007/s10811-017-1152-0.

Prakash, A., \& Vuppu, S. (2014). Punica granatum (pomegranate) rind extract as a potent substitute for $\mathrm{L}$ ascorbic acid with respect to the antioxidant activity. Research Journal of Pharmaceutical, Biological and Chemical Sciences, 5, 597-603.

Raven, J. A., \& Giordano, M (2014). Algae. Current Biology, 24(13), 590595. http://dx.doi.org/10.1016/j.cub.2014.05.039. PMid:25004359.

Rizwana, H., Alwhibi, M. S., \& Soliman, D. A. (2016). Antimicrobial activity and chemical composition of flowers of Matricaria aurea a Native Herb of Saudi Arabia. International Journal of Pharmacology, 12(6), 576-586. http://dx.doi.org/10.3923/ijp.2016.576.586.

Samaraweera, A. M., Vidanarachchi, J. K., \& Kurukulasuriya, M. S. (2012). Industrial applications of macroalgae. West Sussex. UK.: John Wiley \& Sons Ltd.

Santos-Sánchez, N. F., Salas-Coronado, R., Villanueva-Cañongo, C., \& Hernández-Carlos, B. (2019). Antioxidant compounds and their antioxidant mechanism. In Antioxidants (pp. 1-29). London: IntechOpen. http://dx.doi.org/10.5772/intechopen.85270.

Schomburg, D., \& Salzmann, M. (1991). Enzyme Handbook 4 (Vol. 4, pp. 7). Berlin-Heidelberg, Germany: Springer-Verlag http://dx.doi. org/10.1007/978-3-642-76729-6.

Shanura Fernando, I. P., Asanka Sanjeewa, K. K., Samarakoon, K. W., Lee, W. W., Kim, H. S., Ranasinghe, P., Gunasekara, U. K. D. S. S., \& Jeon, Y. J. (2018). Antioxidant and anti-inflammatory functionality of ten Sri Lankan seaweed extracts obtained by carbohydrase assisted extraction. Food Science and Biotechnology, 27(6), 1761-1769. http:// dx.doi.org/10.1007/s10068-018-0406-1. PMid:30483441.

Ul-Haq, I., Ullah, N., Bibi, G., Kanwal, S., Sheeraz Ahmad, M., \& Mirza, B. (2012). Antioxidant and cytotoxic activities and phytochemical analysis of Euphorbia wallichii root extract and its fractions. Iranian Journal of Pharmaceutical Research, 11(1), 241-249. PMid:24250446.

Unnikrishnan, P. S., Suthindhiran, K., \& Jayasri, M. A. (2014). Inhibitory potential of Turbinaria ornata against key metabolic enzymes linked to diabetes. BioMed Research International, 2014, 1-10. http://dx.doi. org/10.1155/2014/783895. PMid:25050371.

Unnikrishnan, P. S., Suthindhiran, K., \& Jayasri, M. A. (2015). Antidiabetic potential of marine algae by inhibiting key metabolic enzymes. Frontiers in Life Science, 8(2), 148-159. http://dx.doi.org/10.1080/ 21553769.2015.1005244.

Vasudevan, D. M., \& Sreekumari, S. (2011). Regulation of blood glucose, insulin and diabetes mellitus. In Textbook of Biochemistry for Medical students (6th ed., pp. 285 -290). New Delhi: Jaypee Brothers Medical Publishers. 
Ismail et al.

Wang, T., Jónsdóttir, R., \& Ólafsdóttir, G. (2009). Total phenolic compounds, radical scavenging and metal chelation of extracts from Icelandic seaweeds. Food Chemistry, 116(1), 240-248. http:// dx.doi.org/10.1016/j.foodchem.2009.02.041.
Yang, H.-W., Fernando, K. H. N., Oh, J.-Y., Li, X., Jeon, Y.-J., \& Ryu, B. (2019). Anti-obesity and anti-diabetic effects of Ishige okamurae. Marine Drugs, 17(4), 1-11. http://dx.doi.org/10.3390/md17040202. PMid:30934943. 